\title{
The Innovation Model of Educational Technology to Strengthen Boarding University Education in Disruptive Era
}

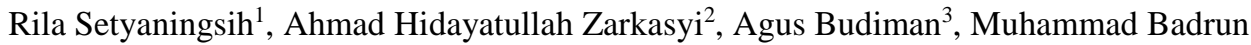 \\ Syahir $^{4}$, Samsirin ${ }^{5}$ \\ \{rilasetya@unida.gontor.ac.id ${ }^{1}$, ahidayatzark@unida.gontor.ac.id ${ }^{2}$, agusbudiman@unida.gontor.ac.id ${ }^{3}$, \\ mbadrun.syahir@unida.gontor.ac.id ${ }^{4}$, samsirin@unida.gontor.ac.id $\left.{ }^{5}\right\}$
}

University of Darussalam Gontor, Jl. Raya Siman Km. 06 Siman, Ponorogo $0^{1,2,3,4,5}$

\begin{abstract}
The disruptive era brings many changes as various kinds of disturbances to arise in various aspects of life, including education. Boarding university as an educational institution should be able to adjust to challenges of the disruptive era in order not to lose competitiveness. This study aims at finding the innovation model of educational technology to strengthen the existence of boarding university in the disruptive era. The study used a qualitative method. Data collection was carried out through observation and interviews with several stakeholders at the University of Darussalam Gontor as a boarding university. The result of this study found the innovation model of educational technology at the University of Darussalam Gontor that was influenced by four elements of innovation diffusion. The four elements are composed of innovation, communication with certain channels, time, and members of the social system. One of the innovations in educational technology was e-learning technology. The contribution of this research is the innovation model of educational technology to strengthen the existence of boarding university, University of Darussalam Gontor.
\end{abstract}

Keywords: innovation, educational technology, boarding university, disruptive era.

\section{Introduction}

An established system can be slowly shifted by an innovation movement, as exemplified by the presence of the disruption era, which brought many changes to the order of social life. The disruptive era has changed the life and work of humans related to changes in the world of technology, known as the industrial revolution 4.0. A system of cyber-physical and the emergence of a virtual world known as IoT (Internet of Things) characterizes the industrial revolution 4.0. Innovation is a positive construct for society because the activities of human life and work are getting more comfortable. However, this could raise various threats and severe disturbances in life if it failed to be conditioned and controlled. The industrial revolution 4.0 requires people to continuously think logically to align themselves with the information development packed through digital media. It also needs people to compete in technology-based innovations. The existence of information technology has intelligently removed time and geographical boundaries, influencing, expanding and replacing the order of life and social systems. 
The disruption era influences various aspects of life, including the world of education. Universities in Indonesia are required to take creative and innovative steps in this new revolution, the primary objective being to produce graduates who are competent and able to compete globally [1]. Universities must be able to condition themselves to face and grow with the disruptive era, and addressing it wisely, or else the higher education institution will be left behind.

Islamic boarding university as an Islamic education institution is also required to adapt to the emergence of the industrial revolution 4.0. It is essential to avoid shocking the appearance of disruption phenomena, where graduates of Islamic education institutions are faced with new challenges that never existed before. They must always innovate, especially in the fields of facilities and infrastructure, resource competencies, curriculum, etc. [2]. Educational technology innovation is essential for Islamic boarding university's effort in facing the industrial revolution 4.0 , through a basic foundation of cyber technology. And to strengthen its existence, the Islamic boarding university must be able to understand the demands of the community and fulfill their needs by making sustainable innovations. It is essential because Islamic boarding school is the "father" of Islamic education in Indonesia, founded because of the demands and needs of the times [3].

The University of Darussalam Gontor is a modern Islamic boarding university that must also self-disrupt, as it is a necessity in the process of change and achievement towards better innovation [4]. This step was carried out by the University of Darussalam Gontor as a manifestation of efforts to compete and defend themselves to strengthen their existence. Therefore, innovation and change are also carried out in the learning process, for example, a computerized system turning towards a cyber technology one. Educational technology innovation is a priority in the development carried out at the University of Darussalam Gontor to face the demands of the times. The university does not want to be unfree in the same weaknesses as those of traditional Islamic boarding schools, i.e., the stigma that Islamic boarding school only teach religious knowledge, limiting the scope of graduate employment which requires having general knowledge, mastery of technology and skills. It is the background of the renewal in modern boarding schools [5]. Educational technology innovation in a modern Islamic boarding university cannot be less important than it is, because it becomes the designer of change and renewal itself.

The University of Darussalam Gontor with a boarding university system requires all students to stay on campus for 24 hours. Furthermore, the rector, staff, and lecturers are also on campus. Lecture activities and integrated boarding life become part of the education dynamic. It makes it easier for lecturers to control, coordinate and evaluate student activities, related to both lectures and boarding life. On the other hand, the existence of the University of Darussalam Gontor campus in several locations creates various obstacles, including distance. Because the gap between the central campus and the branch campus is relatively far, the travel period is time-consuming for the lecturer. Educational technology innovation is an urgent matter to be conducted at the University of Darussalam Gontor to facilitate the learning process and coordination between different campus locations.

One study of educational technology is the diffusion of innovation, where innovation is communicated through media to members of a particular social system at a given time [6]. By carrying out educational technology innovations in the era of industrial revolution 4.0, Islamic boarding universities will be more competitive due to producing graduates who not only master religious knowledge but technology too. Islamic boarding schools can transform and modernize traditional education by adopting and adapting to the demands of the times without sacrificing their principles and objectives [7]. Educational technology innovation is the most significant 
step in changing to the requirements of the era to strengthen the existence of boarding university education, precisely at the University of Darussalam Gontor.

According to The Association for Educational Communications and Technology (AECT) in 2004, educational technology is a field of science that studies general and ethical practices in facilitating and improving learning performance through the creation, use, and management of processes, as well as utilizing the right sources of technology [8]. A focus on the innovation and modernization of Islamic boarding school education conducts researches innovation in education. The results of the study show three aspects in the modernisation, innovation, and renewal of the Islamic boarding school world: the elements of the method, the content of the material, and the management of administration [9]. Other research has been conducted with the topic of Islamic boarding schools among the alpha generation, and challenges faced by the world of education in the new era. The results of the study show that among efforts to develop education, there is a focus on building digital literacy in Islamic boarding schools and create Islamic study channels [10]. More than that, research on technology-based innovation in learning was also carried out with topics on various models of learning change with information technology support. This study illustrates the success of e-learning, distance learning, and the multimedia classroom to enhance innovation of education in the current era of globalization, where learning or interaction between lecturers and students is no longer separated by factors of distance, space and time [11]. In line with the three studies, this study seeks to further explore the educational technology innovation model at the University of Darussalam Gontor to strengthen the existence of boarding university education. Four elements of diffusion of innovation will examine the research: innovation, communication with specific channels, time, and members of the social system to find out the technological innovation model of education at the university.

The innovation of education is important in giving birth to a modernized Islamic civilization [12]. This research was conducted to support the ideals of The University of Darussalam Gontor in becoming a high quality and meaningful university and promote the idea of it being "the fountain of wisdom."

\section{Research methods}

To find a technological innovation model of education conducted by the University of Darussalam Gontor, and to strengthen its existence in the disruptive era, this research was carried out using qualitative descriptive methods. The data in this study was obtained through direct observation and in-depth interviews. Observations of educational and boarding activities were carried out, and policymakers at the University of Darussalam Gontor were interviewed. In-depth interviews were done regarding the diffusion elements of innovation that influence educational technology innovation, including; the element of innovation, communication with specific channels, time, and members of the social system.

After the observations and in-depth interviews were complete, the researcher constructed the messages obtained from the informants and mapped the educational technology innovation models conducted by the University of Darussalam Gontor. The data analysis technique was based on Miles and Huberman's theory, which consists of a few stages: data reduction, data display, and data conclusions according to the interpretation of the researcher. The reduction is made by summarising, choosing the main aspects, and focusing on the most significant ones. Data presentation is in the form of brief descriptions, charts, etc. Concluding/verification is the 
third path in data analysis techniques after data reduction and presentation. The validity of the research data by triangulation checking, where observation and interview techniques are combined, and source triangulation combines data sources from several research subjects.

\section{Research results}

This study found an educational technology innovation model at the University of Darussalam Gontor to strengthen boarding university education in a disruptive era. An examination must be made on the diffusion process of innovation as one of the studies of educational technology to find a model of educational technology innovation. The diffusion of innovations studied consists of the four elements as mentioned earlier: innovation, communication in specific channels, time, and members of the social system.

The first element is innovation, where an idea, product, phenomenon, or method is observed as something new for a person or group of people, both in the form of inventions and discovery that are made to achieve specific goals [13]. Based on the results of the study, it is known that the innovation that took place at the University of Darussalam Gontor was in the form of adoption and adaptation of e-learning models. Electronic or e-learning is a new way of teaching by using information and communication technology [14]. Learning content developed is creative and innovative, and can facilitate college participants in understanding learning materials. E-learning technology developed at the University of Darussalam Gontor uses the Moodle platform, which effectively accommodates the concept of virtual learning more fully by consisting of material, pre-test and post-test questions, as well as discussion forums that encourage students and lecturers to interact without having a face to face meeting.

The concept of e-learning encourages a transformation of conventional education to digital forms, both in content and system. It can significantly assist lecturers in conducting distance learning, and learning activities will be more efficient and effective. Learning activities can be done virtually, where lecturers can upload audio, video, animation and image material for students to access and download the material anytime, anywhere. Students can do the pre-test and post-test questions, and direct assessment by lecturers can be given through this website. Elearning technology innovation is beneficial and facilitates the process of teaching and learning at the University of Darussalam Gontor; however, it does not entirely replace the face-to-face learning model used for a long time. It is because the function of e-learning at the University of Darussalam Gontor is a supplement that is considered both optional and complementary. Essentially, e-learning has three functions, and they are to supplement, complement and substitute [14].

The second diffusion element of innovation is the communication channel. Communication is a process that describes the activities of delivering messages between humans that are interactive, relational, and transactional. Communicators send messages to recipients through certain media with specific intentions and objectives [15]. Based on the results of the study, the process of delivering e-learning technology innovations conducted at the University of Darussalam Gontor follows a bottom-up model, that arises from ideas and innovations from the research team and offers to university leaders. It is followed by a top-down model, where elearning is implemented from university leaders and policy owners to lecturers and students. The media used in delivering the innovation is in the form of interpersonal communication through lecturer meetings and WhatsApp groups. 
E-learning technology innovation should not be easily taken for granted. A series of negotiations took place between the actors involved, and variations in educational technology determine the series of these negotiations. In the case of e-learning at the University of Darussalam Gontor, this shows the priority of innovation developing first so that technological capacity also determines the decision. The use of e-learning is driven by the paradigm that lecturers must be able to utilize the existing learning facilities. Besides that, e-learning technology innovation at the University of Darussalam Gontor also makes an effort to support the policy of the Ministry of Communication and Information Technology of the Republic of Indonesia which was delivered in Press Release No. 04/SP/ HM/BKKP/I/2018 about Science and Technology Development in Higher Education during the era of the Industrial Revolution 4.0. As an institution of higher education, the University of Darussalam Gontor seeks to keep ahead of the times while adhering to the principles and values of the five souls (sincerity, simplicity, independence, Ukhuwah Islamiyah, and free spirit) and the existing five-fold.

The third element is time, which is related to when interest in innovation arises, and the speed at which innovation is received. Based on the results of the study, the University of Darussalam Gontor experienced several stages in implementing e-learning technology innovation, i.e., awareness, interest, evaluation, trial, and adoption. The awareness stage had begun to develop during the KKNI training (Kualifikasi Kompetensi Nasional Indonesia Qualifications of Indonesian National Competencies), SNPT (Standar Nasional Pendidikan Tinggi - National Standards for Higher Education) and learning methods in 2016. The application of SNPT and KKNI in universities require lecturers to use innovative media and learning methods, to develop the SCL (student center learning) model. The development of information and communication technology and the existence of the industrial revolution 4.0 demand the Islamic higher education institutions use various learning methods related to digital technology and provide a competitive edge.

The interest stage arises when there is an excellent knowledge transformation through various discussion forums related to learning that open new perspectives or methods to the learning model and strategy. Intensive and complex interactions between University of Darussalam Gontor lecturers gave birth to new products, methods, rules, and perspectives, all of which saw e-learning as one of the developments in educational technology. In the evaluation phase, assessments were carried out and found that the practice of e-learning at the University of Darussalam Gontor did not always run smoothly. The variety of actors and situations determine the process of implementing e-learning at the University. Various conflicts and negotiations occur on the choice of learning models that will be developed, especially from the stakeholders. The complexity of the negotiation process that occurs results in applying the conventional learning model to the e-learning digital learning model.

The trial phase is the testing of the University of Darussalam Gontor e-learning, which has just been applied to five basic subjects in the Communication Studies Program. In the adoption stage, it begins with the implementation of e-learning to lecturers. Starting at the beginning of 2018, policymakers at Communication Science Study Program - the University of Darussalam Gontor have prepared lecturers in basic courses to implement the e-learning concept. Lecturers are trained to be able to upload learning content consisting of material, pre-test, and post-test questions, online assessment, and discussion forums through e-learning websites. The transformation of knowledge that occurs in lecturers have yet to reach optimum. Internal and external groups cause the problems that arise. That is what makes lecturers challenging to apply the concept of e-learning. The implementation of e-learning that occurs in the University of Darussalam Gontor Communication Science Study Program still feels less than optimal because 
it has not been thoroughly tested and implemented for students. The plan for trial and implementation to students is in 2019.

The fourth element of educational technology innovation diffusion is a member of the social system, e.g., who is involved in the innovation process. In this study, it is known that some people involved in the process consist of university leaders, policymakers at the University of Darussalam Communication Science Study Program Gontor, lecturers, and students. University leaders have a role in determining policies related to the implementation of e-learning. The policymakers in Communication Science Study Program are the initiation of ideas and drivers of e-learning technology innovation. Lecturers and students become actors who are directly involved in the use of e-learning.

Based on the analysis, found an educational technology innovation model to strengthen the existence of boarding university education as shown in figure 1 .

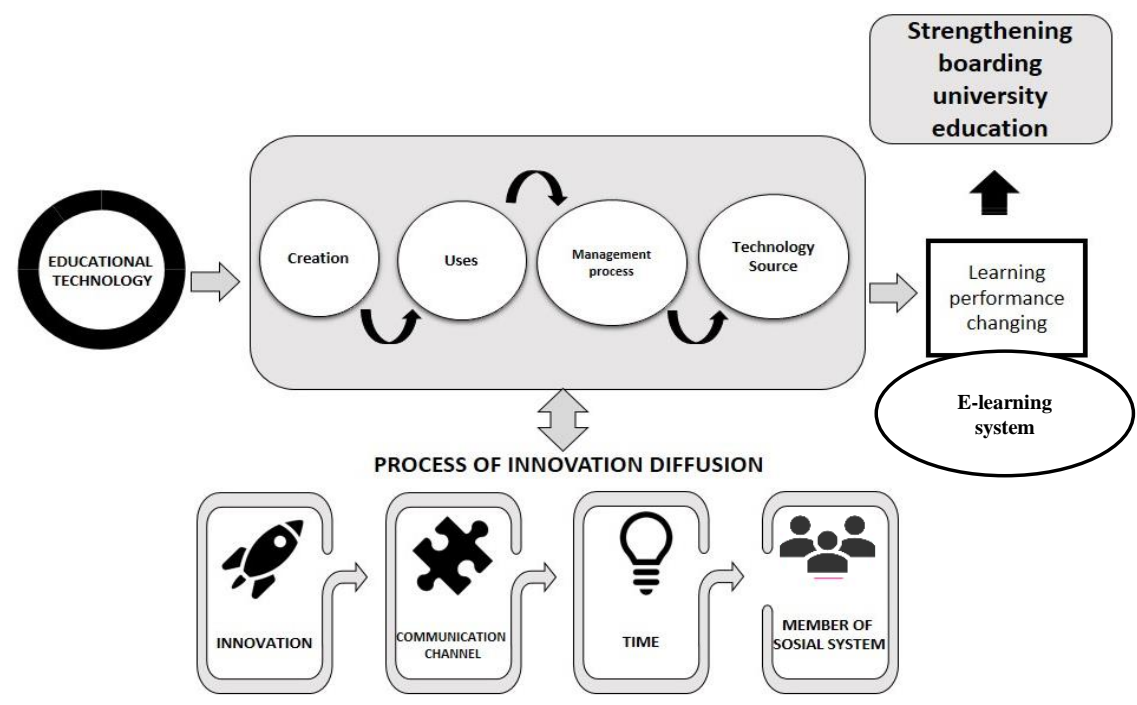

Fig. 1. Educational technology innovation model at the boarding university.

Educational technology is a field of science that studies theoretically and ethical practices in facilitating and improving learning performance through the creation, uses management process, and technological resources. Four elements of innovation diffusion influenced educational technology innovation at the University of Darussalam Gontor. The four elements are composed of innovation, communication channel, time, and member of the social system. The innovations in educational technology at the University of Darussalam Gontor was elearning technology. The educational technology innovation in the form of e-learning system is one type of effort to strengthen the existence of boarding university education in the disruptive era. 


\section{Conclusion}

This study found an educational technology innovation model at the University of Darussalam Gontor in strengthening its existence in the era of disruption. Educational technology innovation at the University involves four elements of innovation diffusion: elements of innovation, communication with specific channels, time, and members of the social system. In this context, the innovations that developed is e-learning technology, e.g., a new way of learning by using information and communication in digital networks. The contribution of this study is a model of educational technology innovation to strengthen the existence of the University of Darussalam Gontor. Research on the effectiveness of educational technology needs to be conducted to measure whether the innovations carried out can be sustained. The research recommendations are aimed at the policymakers at the University of Darussalam Gontor to maximize the use of e-learning as educational technology innovation and continue to strengthen its existence in the disruptive era.

\section{References}

[1] C. Melinda, "Challenges of Lecture in Industrial Era 4.0," in Seminar Nasional Universitas Pasir Pengairan, 2011, pp. 33-36.

[2] S. Priatmoko, "Memperkuat Eksistensi Pendidikan Islam Di Era 4.0," TA'LIM J. Stud. Pendidik. Islam, vol. 1, no. 2, pp. 1-19, 2018.

[3] R. Mar'ati, "PESANTREN SEBAGAI BASIS PENDIDIKAN KARAKTER; TINJAUAN PSIKOLOGIS," AL-MURABBI J. Stud. Kependidikan dan Keislam., vol. 1, no. 1, pp. 1-15, 2014.

[4] R. P. Pamungkas, Tri Yuda Bekti; Winahyu, "CREATIVE THINKING SKILL AS AN IMPORTANT ASPECT IN DISRUPTIVE ERA," in 1st National Seminar on Elementary Education (SNPD 2018), SHEs: Conference Series 1 (1) (2018), 2018, pp. 911-916.

[5] M. Nurhakim, "Imam Zarkasyi Dan Pembaharuan Pesantren : Rekonstruksi Aspek Kurikulum, Menejemen Dan Etika Pendidikan,” Progresiva, vol. 5, no. 1, pp. 83-96, 2011.

[6] M. Yaumi, "Integrasi Teknologi Informasi dan Komunikasi Dalam Pembelajaran," Lentera Pendidik., vol. 14, no. 1, pp. 88-102, 2011.

[7] A. S. Rizal, "Transformasi Corak Edukasi Dalam Sistem Pendidikan Pesantren Dari Pola Tradisi ke Pola Modern,” Pendidik. Agama Islam, vol. 9, no. 2, pp. 95-112, 2011.

[8] A. Nurdyansyah; Widodo, Inovasi Teknologi Pembelajaran. Sidoarjo: Nizamia Learning Center, 2015.

[9] M. Hasan, "INOVASI DAN MODERNISASI PENDIDIKAN PONDOK PESANTREN," KARSA J. Sos. dan Budaya Keislam., vol. 23, no. 2, pp. 295-305, 2016.

[10] E. Gazali, "PESANTREN DI ANTARA GENERASI ALFA DAN TANTANGAN DUNIA PENDIDIKAN ERA REVOLUSI INDUSTRI 4.0,” 2018.

[11] A. Lahinta, "Berbagai Model Inovasi Pembelajaran dengan dukungan Teknologi Informasi," in Seminar Internasional APTEKINDO, 2012, pp. 9-15.

[12] H. M. Baidlawi, "Modernisasi Pendidikan Islam ( Telaah Atas Pembaharuan Pendidikan di Pesantren)," Tadris, vol. 1, no. 2, pp. 154-167, 2006.

[13] Rusdiana, Konsep Inovasi Pendidikan. Bandung: Pustaka Setia, 2014

[14] K. Khamidah and R. A. Triyono, "Pengembangan Aplikasi E-Learning Berbasis Web Dengan Php Dan MySql Studi Kasus Smpn 1 Arjosari," IJNS-Indonesian J. Netw. Secur., vol. 2, no. 2, pp. 17, 2013.

[15] F. W. Lubis, "Peranan Komunikasi Dalam Organisasi," J. Harmon. Sos., vol. 2, no. 2, pp. $53-$ $57,2008$. 